\title{
Endemic Skeletal Fluorosis
}

\author{
M. TEOTIA, S. P. S. TEOTIA, and K. B. KUNWAR \\ From 'Wellcome' Metabolic Laboratory, Department of Medicine, King George's Medical College, Lucknow (India)
}

Teotia, M., Teotia, S. P. S., and Kunwar, K. B. (1971). Archives of Disease in Childhood, 46, 686. Endemic skeletal fluorosis. Endemic skeletal fluorosis is described in 6 children aged 11 or over. Four cases were crippled with severe deformities in the spine, hips, and knees. All showed positive phosphorus, magnesium, and nitrogen balances and excessively positive calcium balances. The skeletal $x$-rays, histology, and chemical composition of the bones revealed diagnostic changes in each case.

Endemic fluorosis as manifested by mottled dental enamel and by diffuse osteosclerosis of the skeleton was first described in India from the State of Madras by Shortt et al. (1937). Subsequently cases have been described from other parts of India (Pandit et al., 1940; Daver, 1945; Khan and Wig, 1945; Siddiqui, 1955; Singh et al., 1962; Singh et al., 1963; Singh, 1967; Teotia, Kunwar, and Teotia, 1969; Jolly et al., 1969; Reddy, Mallikharjunarao, and Sarada, 1969); and from other countries where the drinking water contains excessive quantities of natural fluoride (Dean, 1933; Ockerse, 1944; Lyth, 1946; Hamamoto et al., 1954; Zipkin et al., 1958; Azar et al., 1961).

The only report on endemic fluorosis in children is that of Teotia et al. (1969) who described it in 3 children aged 11 to 13 years. One of their cases had crippling fluorosis and improved considerably on a low calcium diet. Here we describe our further observations on endemic fluorosis in children.

\section{Materials and Methods}

Twenty-two children (15 male and 7 female) aged 6 to 14 years were investigated for skeletal fluorosis. All belonged to poor socioeconomic strata and had lived since birth in an endemic fluorosis area, namely the Madheya Khan Ka Purwa in the district of Rai Bareli Uttar Pradesh, India. For the survey of skeletal fluorosis all the cases had $x$-rays of the spine and the bones of forearms. The diagnostic radiological findings were observed only in 6 children aged 11 or more, though all the children had dental mottling. The subsequent investigations therefore were confined only to the 6 children who had skeletal fluorosis.

Laboratory investigations performed in each case included serum calcium, serum phosphorus, serum magnesium, alkaline phosphatase, blood urea, creatinine

Received 22 March 1971. clearance, chemical analysis of bone ash for calcium, phosphorus, magnesium, and fluoride. The histology of decalcified and undecalcified sections of the biopsied iliac crest bone was studied. In 3 children detailed phosphorus, magnesium, and nitrogen balances were studied on a normal diet. The fluoride content of the bone, drinking water, and urine samples was determined by the procedure based upon diffusion of hydrogen fluoride, as detailed by Singer and Armstrong (1965).

\section{Observations and Results}

These have been summarized in Tables I, II, III, IV, and V and Fig. 1, 2, 3, 4, and 5.

Clinical features. These are recorded in Table I. Of the 6 patients, 5 were male and 1 female, their ages ranged from 6 to 14 years and the duration of the symptoms from 1 to 10 years. The usual symptoms were vague pains, restricted joint movements, backache, stiffness and rigidity of spine, inability to close fists, and constipation. The onset was insidious with a progressive course. The grossly limited movements of spine, thoracic kyphosis, and flexion deformites at the hips and knees, suggesting crippling fluorosis, were present in 4 patients. One of these had generalized forward flexion, fixed chest with minimal expansion, extreme fixity of spine, and the body moved as a single unit whenever an attempt was made to straighten it, providing a grim picture of the result of excessive fluoride intake (Fig. 1).

Dental fluorosis. Mottled discoloration of the teeth was observed in 5 of the 6 cases. Dental $x$-rays revealed resorption of the alveolar bone around the roots of the teeth as a common finding. Thinning or irregular lamina dura was observed in 1 child. 


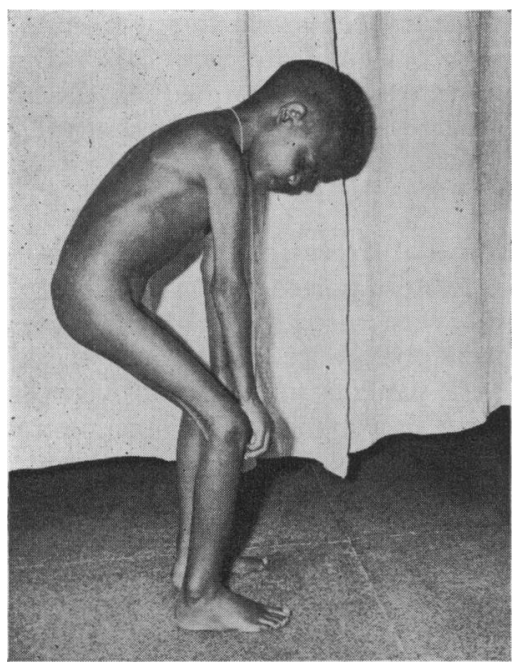

Fig. 1.-Case 2, a child with crippling fluorosis, showing clinical invalidism with marked deformities of the spine and joints.

Skeletal $x$-rays (Fig. 2 and 3). All 6 cases showed osteosclerosis of the spine and pelvis: 4 cases showed coarse trabeculation with cystic changes in the knees and elbows and the calcification of the interosseous membrane of the forearm. The calcification of the capsule of the hip joint was seen in one case.

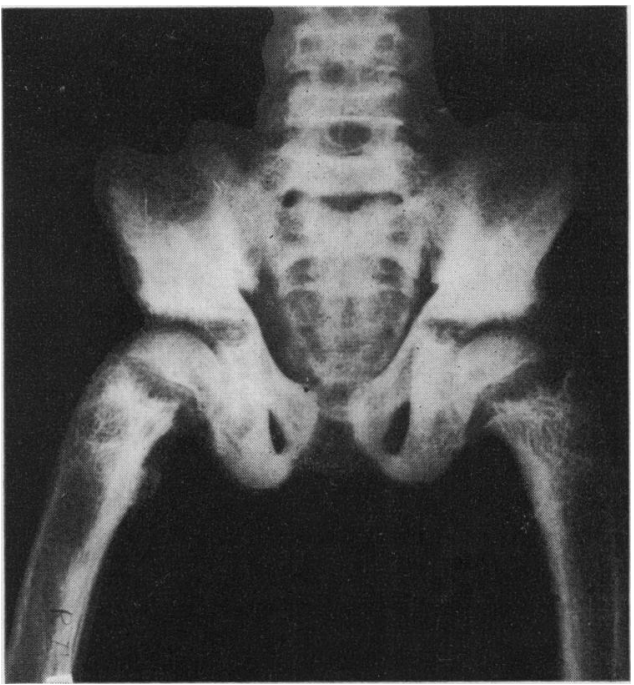

FIG. 2.-X-ray of Case 2 showing oesteosclerosis of the pelvis with coarse trabeculations. The erosions of the femoral neck metaphyses suggest hyperparathyroidism presumably secondary to the fluorosis. The nervly-formed bones show areas of gross rarefaction suggestive of neoosseous porosis.

Histopathological data (Fig. 4 and 5). Histology of the undecalcified sections of the bone obtained from the iliac crest by open biopsy

TABLE I

Clinical Findings in 6 Children with Skeletal Fluorosis

\begin{tabular}{|c|c|c|c|c|c|c|c|c|c|c|c|}
\hline $\begin{array}{l}\text { Case } \\
\text { No. }\end{array}$ & Sex & $\begin{array}{l}\text { Age } \\
(\mathrm{yr})\end{array}$ & $\begin{array}{c}\text { Duration } \\
\text { of } \\
\begin{array}{c}\text { Symptoms } \\
\text { (yr) }\end{array}\end{array}$ & Walking & $\begin{array}{l}\text { Skeletal } \\
\text { Pain } \\
\text { and } \\
\text { Tenderness }\end{array}$ & Spine & Joints & Muscular & $\begin{array}{c}\text { Gastro- } \\
\text { intestinal }\end{array}$ & Chest & $\begin{array}{c}\text { Mottled } \\
\text { Discolora- } \\
\text { tion of } \\
\text { Teeth }\end{array}$ \\
\hline 1 & $\mathbf{M}$ & 12 & 10 & Inability & - & $\begin{array}{l}\text { Stiffiness, } \\
\text { cervical } \\
\text { flexion }\end{array}$ & $\begin{array}{l}\text { Pains, } \\
\text { flexion at } \\
\text { hips and } \\
\text { knees }\end{array}$ & $\begin{array}{l}\text { Inability to } \\
\text { close fist }\end{array}$ & $\begin{array}{l}\text { Constipa- } \\
\text { tion }\end{array}$ & - & Absent \\
\hline 2 & $\mathbf{M}$ & 11 & 3 & Inability & Severe & $\begin{array}{l}\text { Backache, } \\
\text { stiffness, } \\
\text { cervical } \\
\text { flexion, } \\
\text { thoracic } \\
\text { kyphosis, } \\
\text { generalized } \\
\text { forward } \\
\text { flexion }\end{array}$ & $\begin{array}{l}\text { Pains, } \\
\text { flexion at } \\
\text { hips, } \\
\text { knees, and } \\
\text { elbows }\end{array}$ & $\begin{array}{l}\text { Inability to } \\
\text { close fist }\end{array}$ & $\begin{array}{l}\text { Constipa- } \\
\text { tion }\end{array}$ & $\begin{array}{c}\text { Fixation } \\
\text { of chest }\end{array}$ & $\begin{array}{c}\text { Yellowish } \\
\text { brown }\end{array}$ \\
\hline 3 & $\mathbf{M}$ & 14 & $3 \frac{1}{2}$ & - & - & $\begin{array}{l}\text { Backache, } \\
\text { stiffness }\end{array}$ & Stiffness & $\begin{array}{l}\text { Inability to } \\
\text { close fist }\end{array}$ & $\begin{array}{l}\text { Constipa- } \\
\text { tion }\end{array}$ & - & Brown \\
\hline 4 & $\mathrm{~F}$ & 13 & 4 & Difficulty & - & $\begin{array}{l}\text { Stiffness, } \\
\text { cervical } \\
\text { flexion, } \\
\text { thoracic } \\
\text { kyphosis }\end{array}$ & $\begin{array}{l}\text { Stiffness, } \\
\text { painful } \\
\text { movements }\end{array}$ & $\begin{array}{l}\text { Inability to } \\
\text { close fist }\end{array}$ & 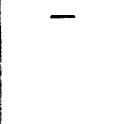 & $\begin{array}{c}\text { Fixation } \\
\text { of chest }\end{array}$ & $\begin{array}{c}\text { Yellowish } \\
\text { brown }\end{array}$ \\
\hline 5 & $\mathbf{M}$ & 11 & 1 & Limping & - & - & - & $\begin{array}{l}\text { Inability to } \\
\text { close fist }\end{array}$ & - & - & $\begin{array}{c}\text { Brown } \\
\text { pitting }\end{array}$ \\
\hline 6 & $\mathbf{M}$ & 12 & - & - & - & - & - & - & - & - & Brown \\
\hline
\end{tabular}




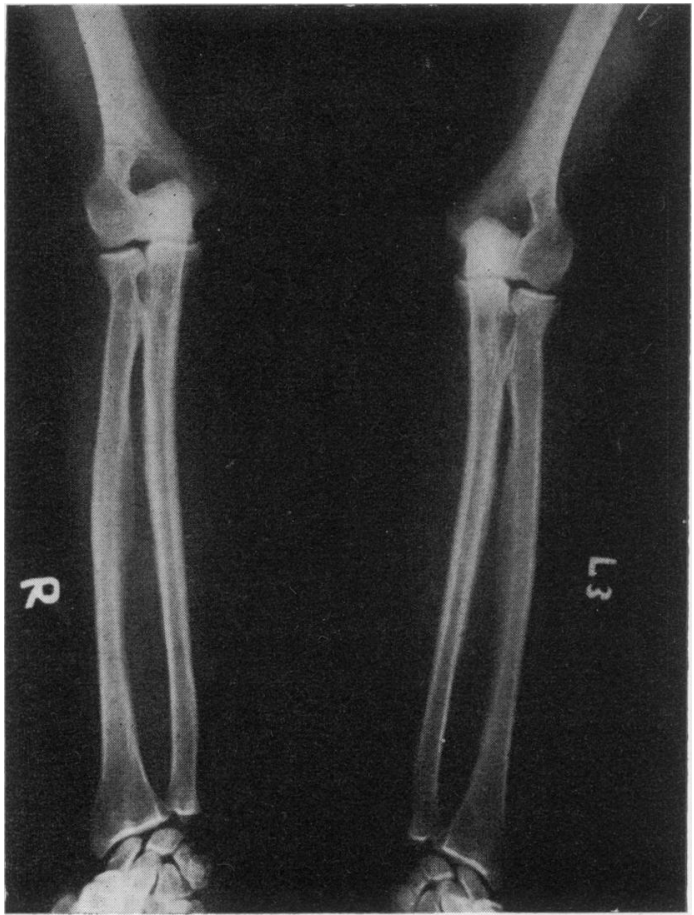

FIG. 3.-X-ray of Case 5 showing calcification of interosseous membrane of the forearms as a diagnostic feature. showed thick trabeculae which appeared to contain an excess of calcium in each case. Decalcified sections revealed a poorly formed Haversian system, with disordered lamellar orientation of the compact bone in 4 cases.

Biochemical investigations. Findings were similar to those reported by us previously (Teotia et al., 1969) with raised serum alkaline phosphatase in 4 (normal below 16 units), and raised serum calcium in 2 patients (normal not over $11 \mathrm{mg} / 100$ $\mathrm{ml}$ ). Serum phosphorus and magnesium were normal (Table II). All showed very positive calcium balances with low urinary excretion of calcium and increased urinary excretion of fluoride (Table III). Table IV gives balance data of phosphorus, magnesium, and nitrogen in 3 children and all showed positive balances. The chemical composition of the iliac bone revealed excess calcium and fluoride, with a slight increase in magnesium. The phosphorus content of the bone did not vary significantly from normal (Table V).

Fluoride in water supply. 20 samples of drinking water were analysed from 4 wells located at different places in the endemic area. They contained $10 \cdot 35-13 \cdot 5$ p.p.m. of fluoride.

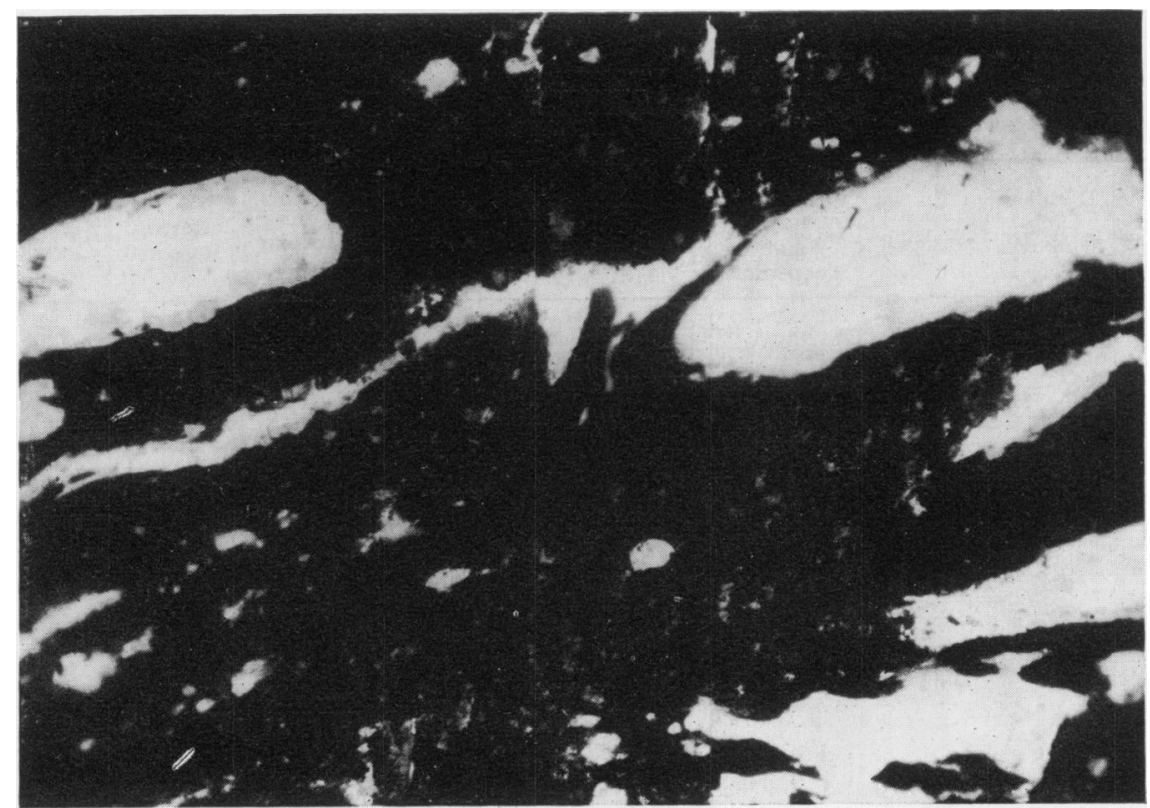

FIG. 4.-Histopathological picture (Case 3) of iliac crest bone biopsy (undecalcified) showing much thickened trabeculae with excessive calcification. $(\times 70$. 


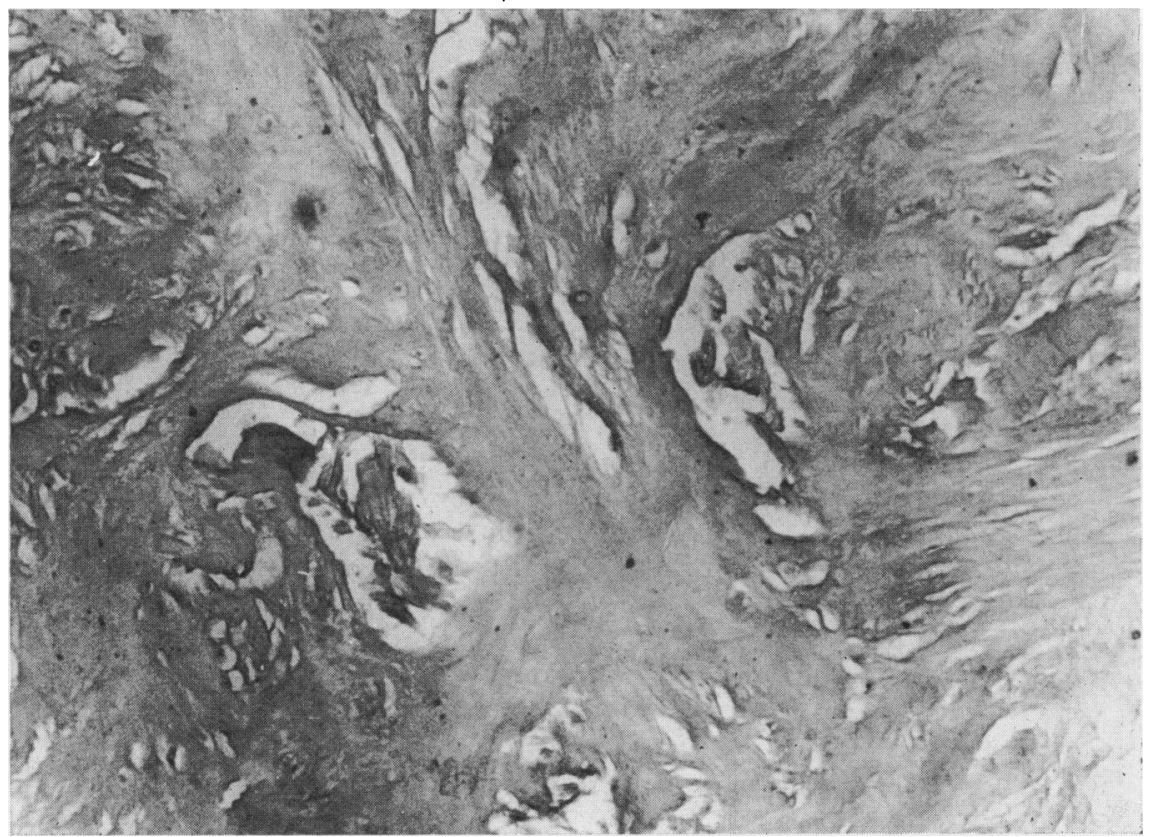

FIG. 5.-Histopathological picture (Case 1) of the iliac crest bone biopsy (decalcified), showing poorly formed Haversian system and disordered lamellar orientation.

\section{TABLE II}

Laboratory Investigations in Patients Studied

\begin{tabular}{|c|c|c|c|c|c|}
\hline \multirow{2}{*}{$\begin{array}{l}\text { Case } \\
\text { No. }\end{array}$} & \multicolumn{4}{|c|}{ Serum } & \multirow{2}{*}{$\begin{array}{l}\text { Fluoride in Drinking } \\
\text { Water (p.p.m.) }\end{array}$} \\
\hline & $\begin{array}{l}\text { Calcium* } \\
(\mathrm{mg} / 100 \mathrm{ml})\end{array}$ & $\begin{array}{l}\text { Phosphorus } \\
(\mathrm{mg} / 100 \mathrm{ml})\end{array}$ & $\begin{array}{c}\text { Alkaline Phosphatase } \\
\text { (KA Units) }\end{array}$ & $\begin{array}{l}\text { Magnesium } \\
(\mathrm{mEq} / \mathrm{l} .)\end{array}$ & \\
\hline $\begin{array}{r}1 \\
+2 \\
3 \\
4 \\
5 \\
6\end{array}$ & $\begin{array}{r}11 \cdot 0 \\
11 \cdot 2 \\
10 \cdot 8 \\
9.5 \\
10 \cdot 0 \\
9.5\end{array}$ & $\begin{array}{l}3 \cdot 8 \\
4 \cdot 2 \\
3 \cdot 0 \\
3 \cdot 5 \\
3 \cdot 8 \\
4 \cdot 2\end{array}$ & $\begin{array}{l}98 \cdot 0 \\
65 \cdot 5 \\
18 \cdot 0 \\
11 \cdot 0 \\
18 \cdot 0 \\
10 \cdot 0\end{array}$ & $\begin{array}{l}1 \cdot 90 \\
1 \cdot 78 \\
1 \cdot 95 \\
2 \cdot 25 \\
1 \cdot 80 \\
2 \cdot 10\end{array}$ & $10 \cdot 4-13 \cdot 5$ \\
\hline
\end{tabular}

*Normal Ca $9 \cdot 0-11 \cdot 0 \mathrm{mg} / 100 \mathrm{ml}$.

tRadiological findings suggested hyperparathyroidism presumably secondary to the fluorosis.

\section{TABLE III}

Calcium Balances (in 6-Day Period) and Urinary Fluoride Excretion in 6 Children with Skeletal Fluorosis

\begin{tabular}{|c|c|c|c|c|c|}
\hline Case No. & $\begin{array}{l}\text { Calcium Intake } \\
(\mathrm{mg} / \mathrm{day})\end{array}$ & $\begin{array}{l}\text { Urine Calcium } \\
\text { (mg/day) }\end{array}$ & $\begin{array}{c}\text { Faecal Calcium } \\
(\mathrm{mg} / \text { day })\end{array}$ & $\begin{array}{l}\text { Calcium Balance } \\
\text { (mg/day) }\end{array}$ & $\begin{array}{l}\text { Urine Fluoride } \\
\text { (p.p.m./day) }\end{array}$ \\
\hline $\begin{array}{l}1 \\
2 \\
3 \\
4 \\
5 \\
6\end{array}$ & $\begin{array}{l}880 \\
890 \\
896 \\
900 \\
900 \\
800\end{array}$ & $\begin{array}{l}38 \\
50 \\
54 \\
46 \\
58 \\
72\end{array}$ & $\begin{array}{l}581 \\
283 \\
570 \\
517 \\
630 \\
980\end{array}$ & $\begin{array}{l}+261 \\
+557 \\
+272 \\
+337 \\
+212 \\
+148\end{array}$ & $\begin{array}{l}3 \cdot 30 \\
2 \cdot 97 \\
3 \cdot 40 \\
2 \cdot 30 \\
2 \cdot 70 \\
2 \cdot 20\end{array}$ \\
\hline
\end{tabular}


TABLE IV

Phosphorus, Magnesium, and Nitrogen Balances in 3 Children with Skeletal Fluorosis

\begin{tabular}{|c|c|c|c|c|c|c|c|c|c|c|c|c|}
\hline \multirow{2}{*}{ Case No. } & \multicolumn{4}{|c|}{ Phosphorus (mg/day) } & \multicolumn{4}{|c|}{ Magnesium (mEq/day) } & \multicolumn{4}{|c|}{ Nitrogen (g/day) } \\
\hline & Intake & Urine & Stool & Balance & Intake & Urine & Stool & Balance & Intake & Urine & Stool & Balance \\
\hline $\begin{array}{l}1 \\
2 \\
3\end{array}$ & $\begin{array}{l}1838 \\
1837 \\
1600\end{array}$ & $\begin{array}{l}1405 \\
1387 \\
1200\end{array}$ & $\begin{array}{l}257 \\
249 \\
270\end{array}$ & $\begin{array}{l}+176 \\
+201 \\
+130\end{array}$ & $\begin{array}{l}14 \cdot 0 \\
16 \cdot 5 \\
16 \cdot 0\end{array}$ & $\begin{array}{l}5 \cdot 8 \\
6 \cdot 2 \\
6 \cdot 0\end{array}$ & $\begin{array}{l}7 \cdot 4 \\
8 \cdot 8 \\
7 \cdot 5\end{array}$ & $\begin{array}{l}+0.8 \\
+1.5 \\
+2.5\end{array}$ & $\begin{array}{l}12 \cdot 1 \\
12 \cdot 4 \\
12 \cdot 0\end{array}$ & $\begin{array}{l}10 \cdot 0 \\
10 \cdot 4 \\
10 \cdot 8\end{array}$ & $\begin{array}{l}1 \cdot 2 \\
1 \cdot 2 \\
1 \cdot 0\end{array}$ & $\begin{array}{l}+0.8 \\
+0.8 \\
+0.2\end{array}$ \\
\hline
\end{tabular}

TABLE V

Chemical Composition of Bone Obtained from Iliac Crest of Patients Studied (Per $100 \mathrm{~g}$ Dry Fat-Free Bone)

\begin{tabular}{c|c|c|c|c}
\hline $\begin{array}{c}\text { Case } \\
\text { No. }\end{array}$ & $\begin{array}{c}\text { Calcium } \\
(\mathbf{g})\end{array}$ & $\begin{array}{c}\text { Phosphorus } \\
(\mathrm{g})\end{array}$ & $\begin{array}{c}\text { Magnesium } \\
(\mathrm{mg})\end{array}$ & $\begin{array}{c}\text { Fluoride } \\
(\mathrm{mg})\end{array}$ \\
\hline $\begin{array}{c}\text { Normal } \\
\text { Patients }\end{array}$ & $11 \cdot 0$ & $5 \cdot 05$ & 105 & \\
1 & $12 \cdot 8$ & $5 \cdot 10$ & 109 & $28 \cdot 5$ \\
2 & $13 \cdot 2$ & $5 \cdot 60$ & 107 & 573 \\
3 & $11 \cdot 5$ & $4 \cdot 90$ & 110 & 605 \\
4 & $12 \cdot 0$ & $4 \cdot 90$ & 115 & 495 \\
5 & $11 \cdot 5$ & $6 \cdot 00$ & 112 & 375 \\
6 & $12 \cdot 5$ & $4 \cdot 80$ & 108 & 180 \\
\hline
\end{tabular}

$\star$ From non-fluorotic area.

\section{Discussion}

Our laboratory findings are similar to those reported by us in adults previously. They showed a rise in serum alkaline phosphatase, low urinary excretion of calcium, and increased urinary excretion of phosphorus and fluoride. None of the children appeared to have developed pubertal changes which could have contributed to a rise in serum alkaline phosphatase. Balance studies revealed retention of phosphorus, magnesium, nitrogen, and calcium. Skeletal $x$-rays were diagnostic of skeletal fluorosis in all cases. Histology of the undecalcified sections of the iliac crest bone biopsies showed thick, well-formed bone trabeculae which appeared to be hypercalcified. Histopathological changes in decalcified sections showed disordered lamellar orientation. Chemical composition of iliac bone revealed an excess content of calcium, fluoride, and magnesium. This indicates a close relation between bone apatite crystal and the composition of the fluids (blood serum) in which crystal formation takes place. The phosphorus content of the bone did not vary significantly from normal.

Our preliminary survey has shown that endemic skeletal fluorosis is not uncommon in children. For the diagnosis of skeletal fluorosis, a simple clinical examination is not enough because other- wise many cases will go undetected. Though dental mottling and pigmentation is one of the earliest signs of chronic fluoride intoxication, its absence does not exclude the affection of the skeletal system.

In our present study we have found that the $x$-rays of the spine for osteosclerosis and of the forearms for the periosteal bone formation and the interosseous membrane ossification are accurate enough for the diagnosis of skeletal fluorosis in children in early stages.

Though skeletal fluorosis in adults has been known for a long time, the reports on skeletal fluorosis in children are rare, and so far as we know the only published report available is by Teotia et al. (1969). Shortt et al. (1937) were of the opinion that residence of 30 to 40 years in an endemic area was necessary for a definite picture of skeletal fluorosis to develop. Jolly et al. (1969) reported that the advanced stage of fluoride intoxication usually resulted from the continuous exposure of an individual to $20-80 \mathrm{mg}$ fluoride ion daily over a period of 10 to 20 years, and such a heavy exposure is associated with a level of at least 10 p.p.m. in the water supply. Siddiqui (1955) reported that skeletal fluorosis could occur with shorter periods of exposure if the fluoride content of water was exceptionally high. However, our findings are contrary to these reports and have shown that skeletal fluorosis is common in children and can occur at a very young age (11-14 years). On the basis of our work we recommend that all children living in endemic zones regardless of the symptoms and dental mottling should be screened for skeletal disease, since its early diagnosis will help in preventing the crippling state of the disease.

We are most grateful to Professor C. E. Dent, F.R.S., of University College Hospital Medical School, London, for his advice and helpful criticism of the manuscript.

REFERENCES

Azar, H. A., Nucho, C. K., Bayyuk, S. I., and Bayyuk, W. B. (1961). Skeletal sclerosis due to chronic fluoride intoxication. Cases from an endemic area of fluorosis in the region of the Persian Gulf. Annals of Internal Medicine, 55, 193. 
Daver, M. B. (1945). Occurrence of fluorosis in endemic forms in Hyderabad State. Indian Medical Gazette, 80, 332.

Dean, H. T. (1933). Distribution of mottled enamel in United States. Public Health Reports, 48, 703.

Hamamoto, E., Fujiwara, H., Kimoto, H., Furutani, A., Yoshimatsu, M., Oda, N., Chara, T., and Ando, H. (1954). On bone changes observed in residents of high fluoride zone. Proceedings of the Fapanese Academy, 30, 53.

Jolly, S. S., Singh, I. D., Prasad, S., Sharma, R., Singh, B. M., and Mathur, O. C. (1969). An epidemiological study of endemic fluorosis in Punjab. Indian fournal of Medical Research, 57, 1333.

Khan, Y. M., and Wig, K. L. (1945). Chronic endemic fluorosis (with bone affections) in the Punjab. Indian Medical Gazette, 80, 429.

Lyth, O. (1946). Endemic fluorosis in Kweichow, China. Lancet, $1,233$.

Ockerse, T. (1944). Endemic Fluorosis in South Africa. (Thesis, University of the Witwatersrand, Johannesburg.) South African Government Printer, Pretoria. (Abst.)(1945). Bulletin of Hygiene, 20, 20.

Pandit, C. G., Raghavachari, T. N. S., Rao, D. S., and Krishnamurti, V. (1940). Endemic fluorosis in South India: a study of the factors involved in the production of mottled enamel in children and severe bone manifestations in adults. Indian fournal of Medical Research, 28, 533.

Reddy, D. B., Mallikharjunarao, C., and Sarada, D. (1969). Endemic fluorosis. Fournal of the Indian Medical Association, 53, 275.
Shortt, H. E., McRobert, G. R., Barnard, T. W., and Nayar, A. S. M. (1937). Endemic fluorosis in the Madras Presidency. Indian fournal of Medical Research, 25, 553.

Siddiqui, A. H. (1955). Fluorosis in Nalgonda District, HyderabadDeccan. British Medical fournal, 2, 1408.

Singer, L., and Armstrong, W. D. (1965). Determination of fluoride. Procedure based upon diffusion of hydrogen fluoride. Analytical Biochemistry, 10, 495.

Singh, A. (1967). Endemic fluorosis (epidemiology and clinical aspects). Special Report Series, Indian Council of Medical Research, 57.

Singh, A., Jolly, S. S., Bansal, B. C., and Mathur, O. C. (1963). Endemic fluorosis. Medicine, 42, 229.

Singh, A., Vazirani, S. J., Jolly, S. S., and Bansal, B. C. (1962). Endemic fluorosis, with particular reference to dental and systemic intoxication. Postgraduate Medical fournal, 38, 150.

Teotia, S. P. S., Kunwar, K. B., and Teotia, M. (1969). Metabolic studies on skeletal fluorosis with a new approach to its treatment (Preliminary report). Fluoride, 2, 144.

Zipkin, I., McClure, F. J., Leone, N. C., and Lee, W. A. (1958). Fluoride deposition in human bones after prolonged ingestion of fluoride in drinking water. Public Health Reports, 73, 732.

Correspondence to Dr. S. P. S. Teotia, Department of Human Metabolism, L.L.R.M. Medical College, Meerut, India. 